Milorad Filipović ${ }^{1}$

Miroljub Nikolić ${ }^{2}$

Goran Katić $^{3}$
JEL: C01, E17, F43, 011

DOI: 10.5937/industrija43-7450

UDC:330.354:330.322(497.11)"2015/2017" 330.362

Original Scientific Paper

\title{
Shortage of Domestic Savings and Investments as a Barrier to Economic Development
}

\author{
Article history: \\ Received: 24 December 2014 \\ Sent for revision: 29 December 2014 \\ Received in revised form: 6 February 2015 \\ Accepted: 10 February 2015 \\ Available online: 1 April 2015
}

\begin{abstract}
In this paper the main macroeconomic parameters and provided projections of their movements in the Republic of Serbia for the period 20152017 were analyzed. Projections of the main macroeconomic aggregates are based on the use of a tailored financial programming model (MEP1) that represents a set of statistical and econometric methods with a view to correlating the endogenous and exogenous variables of the entire macroeconomic system. The task of the applied financial programming model was to describe two scenarios of economic development of Republic of Serbia until 2017. As the main conclusion of this paper, it can be stated that there is no long-term and sustainable development of Serbia without a significantly higher share of domestic savings in the distribution of GDP as well as changes in its structure in terms of strengthening dinar savings. Main contribution of the paper should be argumentation that development model of Serbia from the first decade of XXI century, based on substantially increased aggregate demand financed from privatization revenues and rising indebtedness of country has to be changed in favour of higher domestic savings, investments and on that ground improved competitiveness of national economy.
\end{abstract}

Keywords: Development, Investments, Savings, Financial programming, Model

\footnotetext{
${ }^{1}$ University of Belgrade, Faculty of Economics, miloradf@ekof.bg.ac.rs

${ }^{2}$ Ministry of Economy, Department for Regional Development and Strategic Analysis of the Economy, Serbia

${ }^{3}$ Republic Secretariat for Public Policy, Serbia
} 
Filipović M. et al.: Shortage of Domestic Savings and Investments as a Barrier to...

\section{Nedostatak domaće štednje i investicija kao ograničenje bržem razvoju}

Apstrakt: U radu su analizirani osnovni makroekonomski parametri i date projekcije njihovog kretanja u period 2015-2017. godine u Republici Srbiji. Projekcije osnovnih makroekonomskih agregata su bazirane na modelu finansijskog programiranja (MEP1) koji uključuje niz statističkih $i$ ekonometrijskih metoda kako bi se povezale endogene i egzogene varijable celog makroekonomskog sistema. Cilj primene posebno razvijenog modela finansijskog programiranja je bio da se analiziraju dva scenarija razvoja Srbije do 2017. godine. U radu su navedeni samo osnovni zaključci do kojih se došlo primenom modela. Osnovni zaključak rada je da bez značajnog podizanja učešća štednje u raspodeli BDP-a nema dugoročnog $i$ održivog razvoja Srbije, a takođe je potrebno $i$ jačanje dinarske štednje. Ključni doprinos rada je izneta argumentacija da model razvoja Srbije iz prve decenije XXI veka zasnovan na rastu agregatne tražnje koji je finansiran prihodima od privatizacije i rastućim zaduživanjem zemlje mora biti zamenjen u korist porasta domaće štednje, investicija i na tome zasnovanoj poboljšanoj konkuretnosti domaće ekonomije.

Ključne reči: Razvoj, investicije, štednja, finansijsko programiranje, model.

\section{Introduction}

Phenomena of "Dutch Disease" is well known in economic literature from 1977 when it was the first time used to stress "resource curse" in The Economist Magazine (Corden, 1984). It was recognized that in some countries sudden and abundant inflow of foreign currency could lead to appreciation of domestic currency, transfer of resources from tradable to nontradable sectors and to discourage domestic exporters while in the same time stimulating import of manufacture products. Most quoted countries where Dutch disease was recognized are oil and gas producers as well as other resource-based economies. In longer term this phenomena leads to deindustrialization of some countries as most of its resources begin to be used in non-tradable sectors, mostly in services, where is no such international competition like it is in manufacturing. Appreciation of domestic currency means that almost all export from such country becomes uncompetitive, problems with deficit in current account and indebtedness starts to grow, but GDP growth (based primarily on service sector) as well as "stable" situation with nominal exchange rate gives impression and illusion to economic decision-makers that such situation is sustainable. This happened with development in Serbia till the beginning of global crisis so it affected domestic economy severely and pressed Serbian economists to define new 
Filipović M. et al.: Shortage of Domestic Savings and Investments as a Barrier to...

development model based on "reindustrialization" of national economy. Very high share of untradeable services and products in GDP formation, at one hand, and high inflow of foreign capital through privatization process in 20012008 on the other hand, lead Serbian economy to a difficult situation of uncompetitive production in almost all sectors and high and rising dependence on further foreign capital inflow as a precondition to keep stable macroeconomic situation (Filipović, 2012). Serbia became a country exposed to most severe consequences of current global economic and financial crisis in the Western Balkans indicated by sharp and turmoil movements of GDP from year to year. Even some of the neighbouring countries have similar performances of their economies in Serbia as the largest country in the region interested to provide guidance and experience (Filipović, 2010).

\section{Initial assumptions}

Based on the analysis of real macroeconomic trends of Serbian economy for the period 2005-2011 and the macroeconomic and statistical relationships between certain observed variables, projections of movements of the main macro aggregates for the period 2013-2017 were prepared. The research is based on the results of prominent studies in the field of macroeconomic modeling, such as: Easterly, 2002; Smets, \& Wouters, 2003; Smets, \& Wouters, 2007; Berg, 2010; Geweke, \& Amisano, 2011; Amisano \& Geweke, 2013; as well as local papers in the stated area: Stamenković, Kovačević, \& etc, 2010; Centar za liberalno-demokratske studije, 2012; and especially from a study "Financial programming model in the case of Serbia" that establishes a complete system of econometric relations between the observed macro variables (Arsić, Mladenović, Nojković, \& Petrović, 2005).

The analysis starts from the fact that the Serbian economy is highly dependent on imports, and that projections realization is largely dependent on developments in the countries that are our major trading partners (primarily Germany, Russia, Italy and the CEFTA countries). The initial hypotheses that are established at the beginning of the analysis and need to be proved, are the following:

1. The high and accelerating growth rates of the national economy, in addition to a series of positive effects, result in appreciation of the domestic currency, i.e. strengthening of the dinar against the euro in the medium- and long-term which is a problem for a lot of domestic exporters, and is de facto a boost for the import economy.

2. This sequence of events is a result of the fact that most of the investments enabling and accelerating the growth of the GDP of the Serbian economy are 
Filipović M. et al.: Shortage of Domestic Savings and Investments as a Barrier to...

financed by foreign accumulation, whether from privatization, foreign direct or portfolio investments and borrowing.

3. There will be no long-term sustainable and high growth and development of Serbia as long as it does not significantly increase the share of domestic savings in the financing of investments; especially a significant increase in dinar savings in the long term, and its share in the total national savings of Serbia.

Projections of the main macroeconomic aggregates for the period 2013-2017 are based on the use of a tailored financial programming model that represents a set of statistical and econometric methods with a view to correlating the endogenous and exogenous variables of the entire macroeconomic system. It allows testing of economic policy by specifying targets to key identities, which consequently translate changes on other variables that are related to it. The model includes elements from the balance of payments, the consolidated budget of Serbia and the expenditure side of GDP, as well as a number of auxiliary variables. The task of the applied financial programming model is to describe two scenarios of economic development until 2017. The applied financial programming model (MEP 1) emphasizes the importance of fiscal and exchange rate policy for controlling domestic demand and correcting balance of payments imbalances. The given financial programming model is an important instrument in the process of medium-term forecasting and testing of alternative scenarios.

\section{Methodology of research}

The research has been based on two separate but interrelated parts: the first is analysis of statistical data related to the performances of Serbian economy in the period after democratic changes from late 2000; second part of research paper is result of implementation of MEP model (Model of Economic Policy) developed to estimate achievements of macroeconomic policy in Serbia.

Statistical base for the first part of research has been obtained from different sources: national statistics system, ministries and government agencies responsible for national economy. Data panel and time series has been used to identify trends and relations in main macroeconomic indicators.

MEP has the goal of testing the economic policies in the medium- and longterm by developing alternative scenarios of economic development of Serbia in the period 2015-2017. In developing the basic scenario, the basic exogenous variables were first determined, and accordingly the model of derived exogenous variables used as inputs in the financial programming of 
Filipović M. et al.: Shortage of Domestic Savings and Investments as a Barrier to...

macroeconomic policy to obtain positions in the consolidated budget, balance of payments and GDP spending. Finally, comparative scenarios of macroeconomic performances have been analyzed between MEP model and Fiscal Strategy of Serbia.

\section{Analysis of economic growth, investment, savings and deficit 2001-2012}

The introduced model of economic development of Serbia in the last decade is based on the implementation of macroeconomic stabilisation and structural (economic and market) reforms especially in the implementation of ownership privatisation, followed by a large inflow of foreign investments. This defined model of economic development should have created institutional and material assumptions for long-term sustainable economic growth and development that would simultaneously enable the growth of personal and public consumption.

The main characteristics of Serbian economy in this observed period were:

- Intensive ownership transformation through privatization process (rising level of "brownfield" investments)

- Low level of domestic savings (as GDP share) compensated by very high inflow of foreign capital

- Efficacy of investments at relatively low level as growing share of investment from GDP is needed just for the stabilization of the macro economic situation

- Intensive deindustrialization of national economy followed by growing share of untradeable services in GDP formation. (Dragutinović, Filipović, \& Cvetanović, (2012).

Although a relatively high average annual rate of real GDP growth of $5.4 \%$, was achieved in the pre-crisis period (2001-2008), the model of economic development was realised through the creation and use of GDP with an unfavourable structure, and a high amount of foreign capital inflow (through direct and portfolio foreign investment, and later, with the crisis outbreak, by direct foreign borrowing). At the same time, low domestic savings were realised leading to an increase in already high level of indebtedness of the domestic economy towards foreign countries in order to enable its more or less stable functioning. With the rapid development of services (primarily nontradable services, which are implemented in the domestic market, such as telecommunications, banking, insurance, trade, transport, etc.), high GDP growth was accomplished, with a significant increase in external imbalances 
Filipović M. et al.: Shortage of Domestic Savings and Investments as a Barrier to...

(creating a high trade and current account deficit). The inflow of foreign direct investment and the volume of foreign borrowing were the main source for the simultaneous coverage of the growing current account deficit and increasing foreign exchange reserves of the country.

The speed and long-term sustainability of development of a country depends largely on the level and quality (efficiency) of investment, because what Serbia needs the most - structural changes in the creation and distribution of GDP, can only be accomplished with new investments. In 2012 the share of investments in the GDP of Serbia amounted to $18.6 \%$, which is the average level of the most developed countries (Major advanced economies - the G7, the European Union, the Euro area and the Advanced Economies), but significantly below the average of countries that achieved rapid economic growth as Developing countries, like Asia (share 42.1\%), Emerging market and developing economies (32.1\%), and the ASEAN-5 (30.7\%). It is well known that achieving rapid economic growth and reaching the level of development of the most developed countries is possible only in those economies that are able to achieve a high level of investment, which is above the world average, or above the level of investment of the most developed countries. Therefore, the indicator that measures the share of investment in GDP is very important because it shows whether a country has enough development capacity for rapid growth and development. Evidence of this is the size of the share of investment in GDP in countries with the highest growth in the world, and the countries that have successfully completed transition, which in different stages of its implementation had a level of investment that exceeded $30 \%$ of GDP, can be taken as an example (see Table 1).

In the period 2001-2012, the share of investments in the GDP of Serbia had a cyclic movement, with the highest share recorded in 2004, 2007 and 2008, close to accounting for $30 \%$ of GDP. The arrival of global economic crisis had negative impact on the level of investment, and in the crisis years (2009-2012) the share of investment in GDP declined to below 20\%, which was insufficient to achieve dynamic economic growth, particularly when taking into account the achieved level of economic development.

One of the main characteristics of Serbian economy besides the relatively low level of investment and high current account deficit is a relatively low level of domestic savings, and dependence on foreign accumulation.

In addition to the level of investment activity, the pace and direction of development of Serbian economy are significantly affected by mode of financing (domestic or foreign accumulation) and the use of investments (whether funds are invested in production and implementation of internationally tradable goods and services, in areas with a high or low valueadded, in propulsive branches with the possibility of gaining long-term 
Filipović M. et al.: Shortage of Domestic Savings and Investments as a Barrier to...

competitiveness in the world market or in activities that cannot achieve a high level of competition, etc.). The structure of domestic savings is also extremely important, since a high level of dinar saving is far more preferable than foreign currency savings.

Table 1. Share of investments in the GDP in the period 2001-2012

\begin{tabular}{|c|c|c|c|c|c|c|c|c|c|c|c|c|}
\hline & 2001 & 2002 & 2003 & 2004 & 2005 & 2006 & 2007 & 2008 & 2009 & 2010 & 2011 & 2012 \\
\hline World & 21.6 & 21.0 & 21.2 & 22.1 & 22.5 & 23.2 & 23.8 & 23.8 & 21.7 & 22.7 & 23.4 & 23.9 \\
\hline $\begin{array}{l}\text { Advanced } \\
\text { economies }\end{array}$ & 20.9 & 20.0 & 20.1 & 20.7 & 21.1 & 21.6 & 21.6 & 21.0 & 17.7 & 18.4 & 18.7 & 18.8 \\
\hline European Union & 20.6 & 19.7 & 19.7 & 20.0 & 20.3 & 21.2 & 22.1 & 21.7 & 18.3 & 18.7 & 19.0 & 18.4 \\
\hline $\begin{array}{l}\text { Newly } \\
\text { industrialized } \\
\text { Asian economies }\end{array}$ & 25.8 & 25.2 & 25.2 & 26.7 & 26.1 & 26.4 & 26.2 & 27.6 & 23.5 & 26.4 & 25.9 & 25.8 \\
\hline Developing Asia & 30.0 & 31.2 & 33.7 & 35.9 & 36.3 & 37.0 & 36.9 & 38.3 & 41.4 & 41.4 & 41.9 & 42.1 \\
\hline $\begin{array}{l}\text { Emerging market } \\
\text { and developing } \\
\text { economies }\end{array}$ & 24.2 & 25.0 & 25.9 & 27.2 & 26.9 & 27.9 & 29.2 & 30.1 & 30.5 & 31.0 & 31.8 & 32.1 \\
\hline ASEAN-5 & 23.8 & 23.8 & 25.2 & 25.0 & 26.3 & 25.3 & 25.1 & 26.6 & 25.5 & 28.7 & 28.6 & 30.7 \\
\hline $\begin{array}{l}\text { Central and } \\
\text { eastern Europe }\end{array}$ & 19.3 & 19.6 & 19.8 & 21.6 & 21.5 & 23.4 & 24.7 & 25.0 & 18.9 & 20.5 & 23.1 & 21.1 \\
\hline $\begin{array}{l}\text { Bosnia and } \\
\text { Herzegovina }\end{array}$ & 26.0 & 28.1 & 28.4 & 26.6 & 26.3 & 20.5 & 26.5 & 28.3 & 20.9 & 19.4 & 18.1 & 18.8 \\
\hline Bulgaria & 20.2 & 19.7 & 21.2 & 22.7 & 27.6 & 32.1 & 34.1 & 37.5 & 29.4 & 22.9 & 23.1 & 24.1 \\
\hline Croatia & 22.5 & 26.1 & 28.1 & 27.4 & 27.8 & 29.9 & 29.9 & 31.3 & 25.9 & 22.7 & 22.0 & 21.8 \\
\hline Hungary & 25.2 & 24.7 & 23.6 & 25.9 & 24.5 & 24.1 & 22.4 & 23.5 & 17.9 & 18.4 & 19.1 & 17.8 \\
\hline Montenegro & 23.4 & 18.8 & 15.4 & 16.6 & 17.7 & 25.4 & 33.8 & 40.7 & 27.1 & 22.8 & 19.4 & 20.3 \\
\hline Romania & 22.2 & 22.0 & 22.0 & 23.7 & 23.3 & 26.5 & 31.0 & 31.3 & 25.4 & 24.8 & 28.8 & 28.9 \\
\hline Serbia & 11.7 & 11.0 & 14.5 & 28.3 & 23.7 & 24.1 & 29.0 & 29.7 & 18.0 & 16.5 & 18.9 & 18.6 \\
\hline $\begin{array}{l}\text { Serbia's rank in } \\
\text { comparison to } \\
13 \text { countries of } \\
\text { Central and } \\
\text { eastern Europe }\end{array}$ & 12 & 12 & 12 & 2 & 7 & 9 & 7 & 7 & 9 & 11 & 10 & 11 \\
\hline
\end{tabular}

Source: according to the data from IMF, World Economic Outlook Database

In Serbia, the share of gross national savings in the GDP in 2012 amounted to only $7.1 \%$, which is significantly lower than the world average (24.0\%), and low when compared to all regions of the world. Broken down by region, the largest share of national savings in GDP is indicated by Developing Asian countries (43.0\%), and other less developed regions (Middle East and North Africa, Emerging market and developing economies, newly industrialised Asian economies, ASEAN-5, etc.). The EU share of gross national savings in GDP is $18.8 \%$, and $16.0 \%$ in Central and Eastern Europe, which is the lowest share of all the observed regions in the world (see Figure 1).

Due to the international comparability and availability of data, the paper uses aggregate gross national savings. This aggregate differs from the aggregate 
Filipović M. et al.: Shortage of Domestic Savings and Investments as a Barrier to...

total domestic savings by including net factor incomes from abroad. The gross national saving rate is defined as gross national income decreased by total consumption, and increased by the amount of net transfers.

Figure 1. Trends in gross national savings as a share of GDP in the period 2001-2012

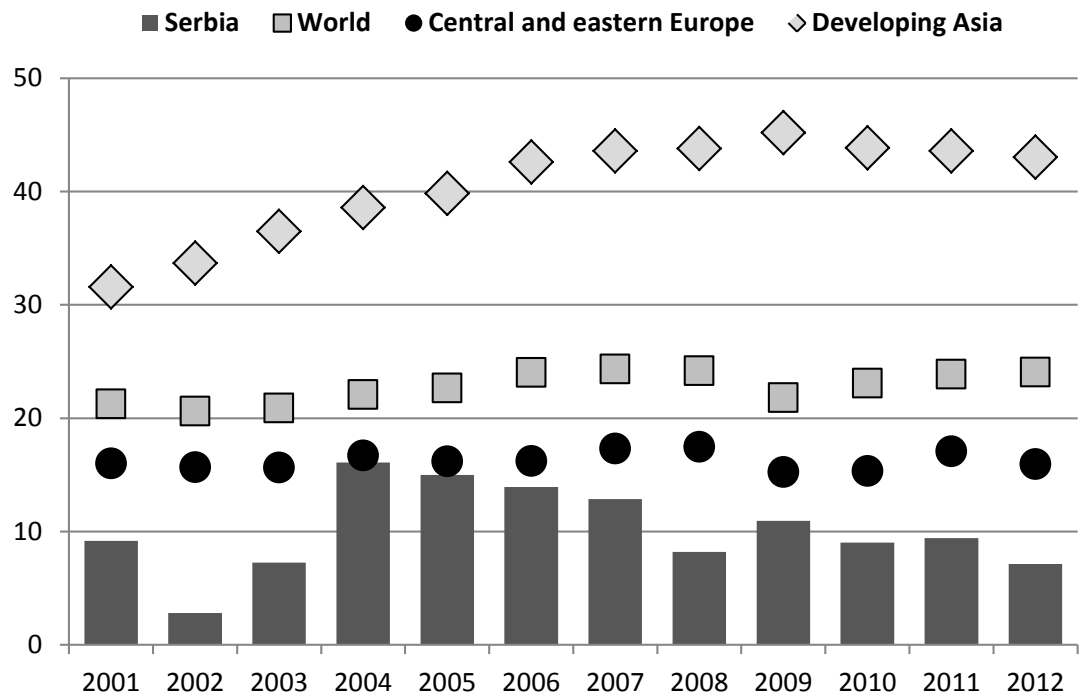

Source: according to the data from IMF, World Economic Outlook Database

Serbia has a lower share of gross national savings in GDP than any individual Central and Eastern European country except Montenegro where this share in 2012 was negative $(-0.9 \%)$. Lithuania, Romania and Bulgaria have the largest share in the region while Albania, Turkey and Bosnia and Herzegovina have the lowest (except Montenegro and Serbia). From 2001 to 2012, the largest share of gross domestic savings in GDP in Serbia was recorded in 2004 (16.1\%), only to drop below $10 \%$ during the $2008-2012$ crisis years (except in 2009 when the share was $10.9 \%$ ), whereby the lowest share of only $7.1 \%$ was recorded in 2012 (see Table 2).

The lower share of gross national savings in GDP in Serbia in relation to the neighbouring countries, as well as unfavourable and declining participation trends of the observed period, indicate that Serbia is lagging behind regarding the possibility of financing the growth and development of domestic savings and dependence on the inflow of funds from abroad. Presuming that financing economic growth largely from foreign accumulation is uncertain, insufficient and unsustainable in the long-term, it can be argued that for achieving 
Filipović M. et al.: Shortage of Domestic Savings and Investments as a Barrier to...

sustainable economic growth and development of Serbia, it is necessary to increase the share of domestic savings in finance investments, where the volume and structure influences the speed and quality of economic growth. Therefore it can be concluded that only an increase in domestic savings (private or public) can provide non-inflationary financing of investments required for sustainable growth. Accordingly, the ability of the domestic economy to increase the share of domestic savings in GDP and to increase the funding of investments from domestic accumulation is one of the key prerequisites for maintaining macroeconomic balance and stability and achieving rapid sustainable economic growth and development.

Table 2. Share of gross national savings in the GDP

\begin{tabular}{|c|c|c|c|c|c|c|c|c|c|c|c|c|}
\hline & 2001 & 2002 & 2003 & 2004 & 2005 & 2006 & 2007 & 2008 & 2009 & 2010 & 2011 & 2012 \\
\hline World & 21.3 & 20.6 & 20.9 & 22.1 & 22.7 & 24.0 & 24.3 & 24.2 & 21.8 & 23.1 & 23.9 & 24.0 \\
\hline $\begin{array}{l}\text { Advanced } \\
\text { economies }\end{array}$ & 20.3 & 19.2 & 19.1 & 20.0 & 20.1 & 20.9 & 20.8 & 19.8 & 17.1 & 18.1 & 18.2 & 18.3 \\
\hline $\begin{array}{l}\text { European } \\
\text { Union }\end{array}$ & 20.2 & 19.8 & 19.8 & 20.6 & 20.3 & 21.0 & 21.8 & 20.9 & 18.2 & 18.7 & 19.3 & 18.8 \\
\hline $\begin{array}{l}\text { Newly } \\
\text { industrialized } \\
\text { Asian } \\
\text { economies }\end{array}$ & 30.3 & 30.3 & 32.0 & 33.2 & 31.9 & 32.5 & 33.4 & 32.6 & 31.2 & 33.7 & 32.6 & 31.5 \\
\hline $\begin{array}{l}\text { Developing } \\
\text { Asia }\end{array}$ & 31.6 & 33.7 & 36.5 & 38.6 & 39.8 & 42.6 & 43.6 & 43.8 & 45.2 & 43.9 & 43.6 & 43.0 \\
\hline $\begin{array}{l}\text { Emerging } \\
\text { market and } \\
\text { developing } \\
\text { economies }\end{array}$ & 24.8 & 26.1 & 27.8 & 29.6 & 30.8 & 32.8 & 33.3 & 33.7 & 32.0 & 32.5 & 33.7 & 33.3 \\
\hline ASEAN-5 & 27.7 & 27.5 & 29.2 & 27.8 & 28.2 & 30.2 & 30.3 & 29.3 & 30.8 & 31.8 & 31.5 & 31.3 \\
\hline $\begin{array}{l}\text { Central and } \\
\text { eastern } \\
\text { Europe }\end{array}$ & 16.0 & 15.7 & 15.7 & 16.7 & 16.2 & 16.2 & 17.3 & 17.5 & 15.3 & 15.4 & 17.1 & 16.0 \\
\hline $\begin{array}{l}\text { Bosnia and } \\
\text { Herzegovina }\end{array}$ & 13.1 & 10.5 & 9.2 & 10.4 & 9.3 & 12.6 & 15.8 & 14.2 & 14.6 & 13.7 & 9.4 & 10.9 \\
\hline Bulgaria & 14.7 & 17.3 & 15.8 & 16.3 & 15.9 & 14.6 & 8.9 & 14.5 & 20.4 & 21.8 & 24.0 & 23.8 \\
\hline Croatia & 19.4 & 18.9 & 22.1 & 23.3 & 22.5 & 23.2 & 22.7 & 22.4 & 20.8 & 21.6 & 21.1 & 20.6 \\
\hline Hungary & 21.1 & 18.7 & 16.7 & 18.5 & 17.1 & 16.7 & 15.2 & 16.2 & 17.8 & 19.6 & 20.5 & 20.4 \\
\hline $\begin{array}{l}\text { FYR } \\
\text { Macedonia }\end{array}$ & 11.9 & 11.3 & 18.1 & 13.8 & 18.8 & 21.1 & 17.6 & 14.0 & 19.1 & 23.4 & 24.4 & 23.1 \\
\hline Montenegro & 13.4 & 5.5 & 8.7 & 9.5 & 9.4 & 1.6 & -5.1 & 10.0 & -3.1 & -2.6 & -1.3 & -0.9 \\
\hline Romania & 17.8 & 18.7 & 16.1 & 15.3 & 14.7 & 16.1 & 17.6 & 19.7 & 21.2 & 20.4 & 24.4 & 25.2 \\
\hline Serbia & 9.2 & 2.8 & 7.2 & 16.1 & 15.0 & 13.9 & 12.9 & 8.2 & 10.9 & 9.0 & 9.4 & 7.1 \\
\hline $\begin{array}{l}\text { Serbia's rank } \\
\text { in comparison } \\
\text { to } 13 \\
\text { countries of } \\
\text { Central and } \\
\text { eastern } \\
\text { Europe }\end{array}$ & 13 & 13 & 13 & 7 & 10 & 11 & 11 & 12 & 12 & 12 & 13 & 12 \\
\hline
\end{tabular}

Source: according to the data from IMF, World Economic Outlook Database 
Filipović M. et al.: Shortage of Domestic Savings and Investments as a Barrier to...

Apart from the low share of gross national savings in the GDP of Serbia, there is also an unfavourable structure of savings because most of the domestic savings are in foreign currency (EUR). Although RSD savings in Serbia increased more than ten times in the period 2001-2011, from RSD 1,559 million (December 2001) to RSD 15,699 million (October 2011), they are still very modest, but a positive change in the maturity structure aimed at increasing long-term deposits (from 5.2\% in 2001 to $23.1 \%$ in 2011) was noted. Foreign currency savings, over the same period increased from EUR 352 million (RSD 20.994 million) to EUR 7.332 million (RSD 742,235 million) where, as in RSD savings, long-term deposits increased participation (from $1.8 \%$ to 16.9\%) (Barišić and Pepić, 201: 1). Despite the improvements in terms of the maturity (long-term deposit growth) structure of domestic savings, which is dominated by savings in foreign currency, it cannot be seen as favourable with regard to financing the development of Serbia (see Figure 2).

Figure 2. The structure of household savings in banks in Serbia

—Dinar (RSD) savings $\quad$ 口Foreign currency savings

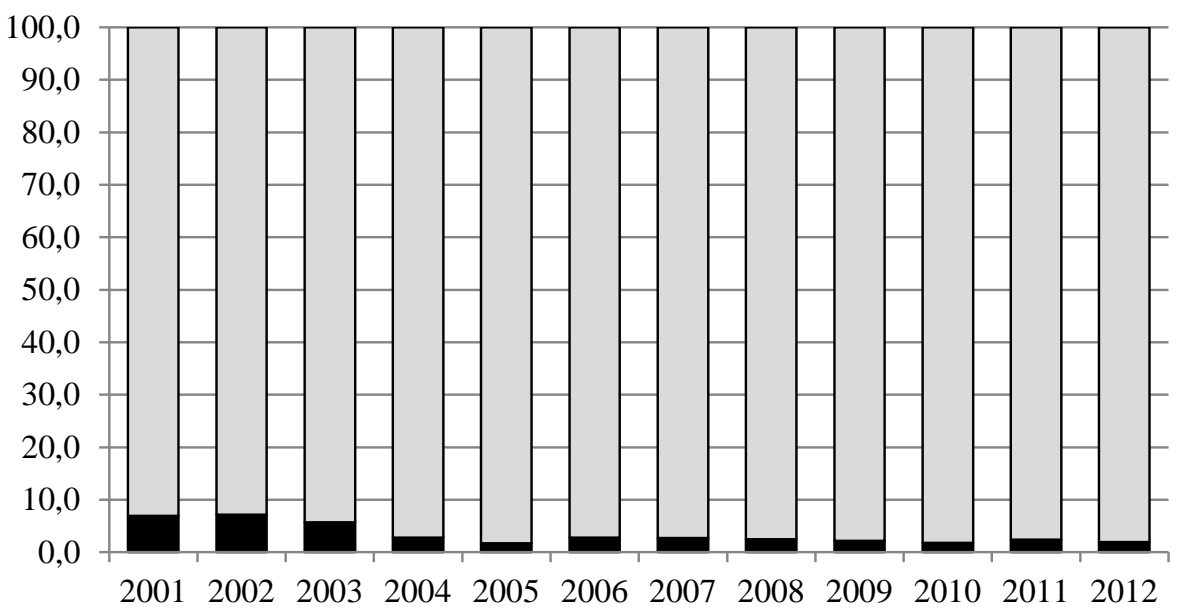

Source: according to the data from the National Bank of Serbia

In a situation where the level of domestic savings is less than volume of investment, gross domestic investment is financed mainly from foreign savings (accumulation). This leads to the formation of the current account deficit, which in our case is accompanied by a suboptimal use of investment compared to the real needs of the economy (many investments are spent in the field of non-tradable goods and services). In this way, the share of tradable goods (agriculture, manufacturing and construction) participated in 
Filipović M. et al.: Shortage of Domestic Savings and Investments as a Barrier to...

the formation of GDP continuously decreasing in the period 2001-2012 (from $42.7 \%$ in 2001 to $31.7 \%$ in 2012) (see Figure 3). This structural phenomenon resulted in reduction of supply of goods for export and increase of demand for imported goods. The independent internal (domestic) demand (and consumption within its framework) grew faster than GDP, which constantly increased the deficit of the current balance of payments. This model of economic development was maintained by financing the deficit of the current part of the balance of payments with inflows of foreign capital, with corresponding surpluses in the balance of financial and capital transactions covering the current deficit, which, constantly expanded with the growth of the trade deficit. The achieved economic growth, with its structure cannot provide stable conditions for sustainable development.

Figure 3. Share of tradable goods in the formation of GDP in Serbia, in \%

$\square$ Agriculture, forestry and fishing $\square$ Manufacturing industry $\square$ Construction

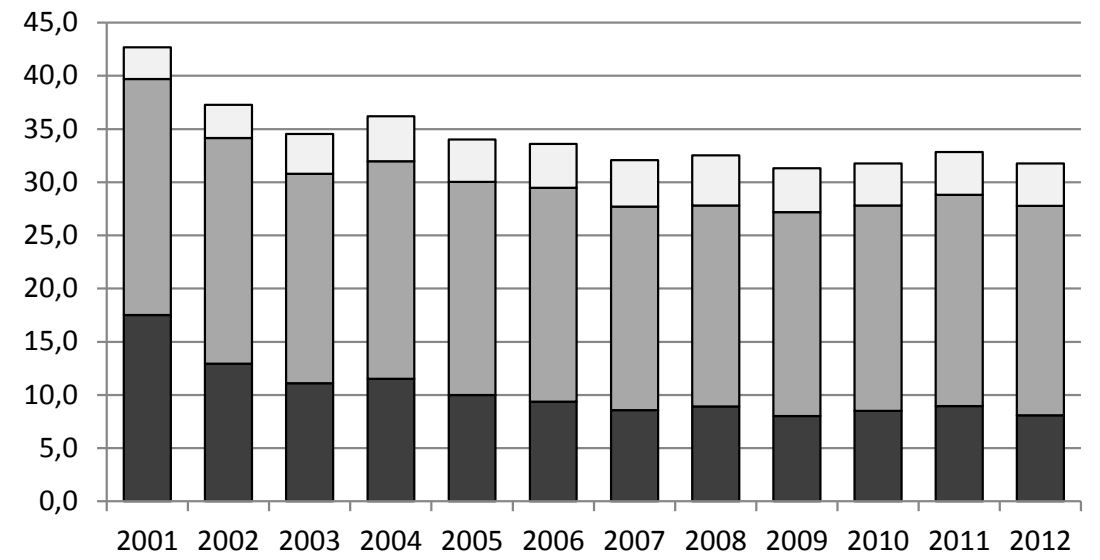

Source: according to the data from Statistical Office of the Republic of Serbia

The pre-crisis period (2001-2008) was characterized by continuous growth in both exports and imports, but at a different pace. Faster growth of imports compared to exports resulted in constant growth of the foreign trade deficit. This several-year trend was interrupted by the crisis period (2009-2012), however, after a sharp decline in exports, imports and the trade deficit in 2009, the earlier trend (simultaneous growth of exports, imports and the deficit) was repeated in 2010 and 2011, but at a lower level. In 2012, Serbia's trade with foreign countries decreased again, exports and imports decreased and the deficit contracted. 
Filipović M. et al.: Shortage of Domestic Savings and Investments as a Barrier to...

Figure 4. Foreign trade, export, import and trade balance of Serbia in the period 2001-2012, in EUR billion

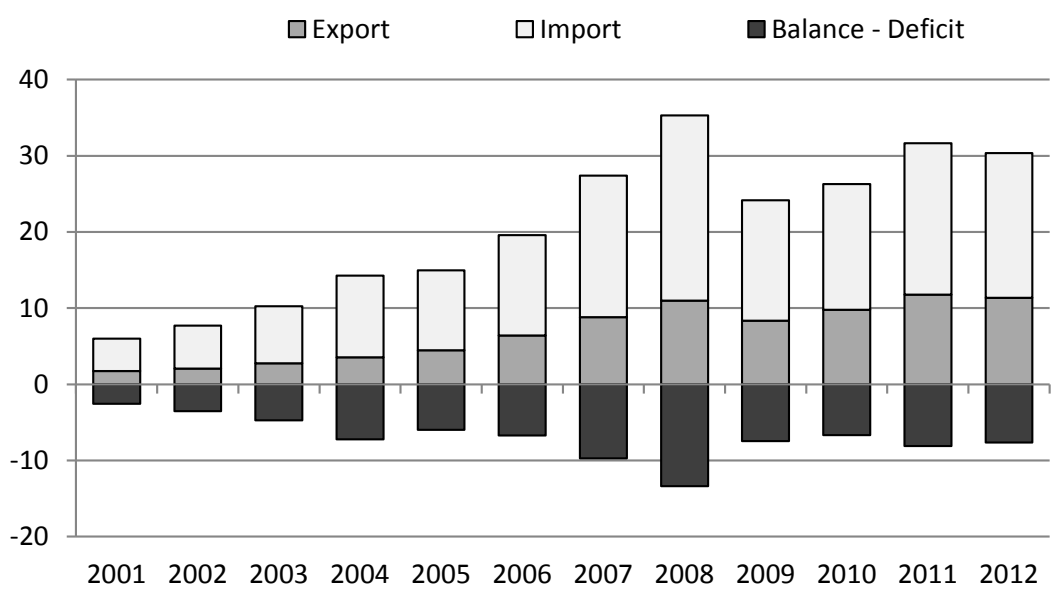

Source: according to the data from Statistical Office of the Republic of Serbia

In period 2001-2012, Serbia generated a trade deficit with foreign countries by having imports higher than exports. In the observed period, exports increased by 9.6 billion USD, while imports in the same period increased by USD 14.7 billion - 1.53 times more than the growth of exports. The faster growth of imports compared to exports caused the trade deficit to rise from USD 2.5 billion in 2001 to USD 13.4 billion in 2008, when the deficit reached its highest value (see Figure 4).

Based on indicators of import dependence it can be concluded that the Serbian economy (production and consumption) is largely dependent on imports. In 2001, import dependence was 37.1\%, while in 2012 it increased to $50.4 \%$. As opposed to high import dependence, export dependence is significantly lower and amounted to $30.1 \%$ in 2012 . This is an increase of 15 percent compared to 2001. High import dependence of the economy combined with low export dependence is not good and is present in less developed countries. In the case of Serbia, indicators of import and export dependence show that the part of the economy in Serbia targeted at exports is significantly less, and the Serbian market is largely open to imported products (see Figure 5). 
Filipović M. et al.: Shortage of Domestic Savings and Investments as a Barrier to...

Figure 5. Main indicators of the relations between Serbian and international markets in the period 2001-2012

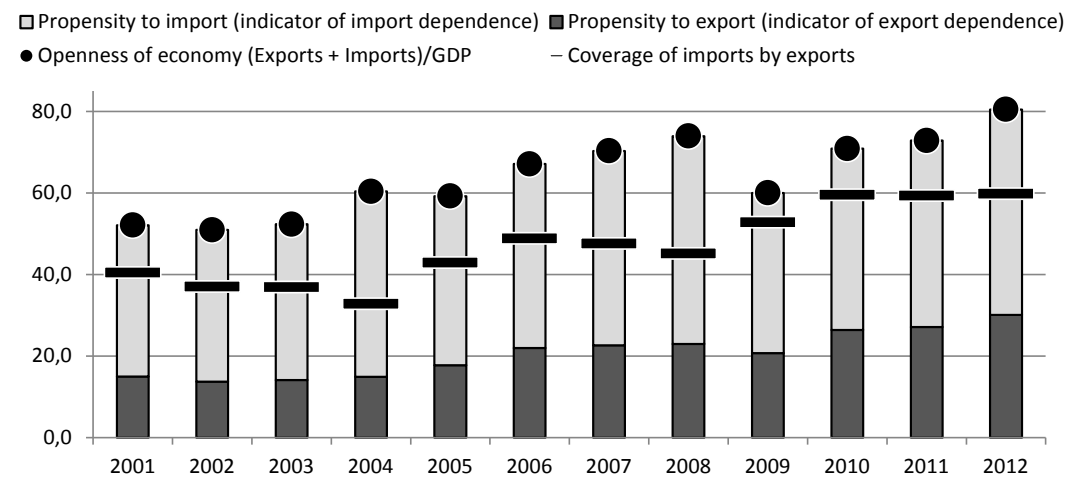

Source: according to the data from Statistical Office of the Republic of Serbia

The openness of the Serbian economy during the observed period ranged from $50.9 \%$ in 2002 to $80.4 \%$ in 2012 . Although openness of the economy above $70 \%$ indicates a relatively high level of openness, if indicators of import and export openness are compared, it can be concluded that the Serbian economy is relatively closed to export and open to import. This means that the economy and market in Serbia are open to imports, and that Serbian exports did not open properly due to lack of competitiveness of Serbian products in the international market. This is a result of inadequate directivity of investment and unstimulating movement of the real exchange rate.

During the observed period, the export-import ratio in Serbia was not adequate; not even in one single year did the total value of exports cover the total value of imports. The lowest coverage of imports by exports was in 2004 (32.8\%), and the highest in 2012 (59.7\%). Although the export-import ratio was more favourable in 2012, the value of deficit remained high. In 2012, the value of the deficit (USD 7.7 billion USD) was lower than in 2007 (USD 9.7 billion), 2008 (USD 13.4 billion) and 2011 (USD 8.1 billion) (see Figure 5)

\section{Financial programming - Model of economic policy}

The development of the financial programming model (Model MEP) has the goal of testing the economic policies in the medium- and long-term by developing alternative scenarios of economic development of Serbia in the period 2015-2017. In developing the basic scenario, the basic exogenous variables were first determined, and based on them the model of derived exogenous variables which were used as inputs in the financial programming 
Filipović M. et al.: Shortage of Domestic Savings and Investments as a Barrier to...

of macroeconomic policy to obtain positions in the consolidated budget, balance of payments and GDP spending. Upon the optional change of targeted variables there is an automatic change in the derived exogenous parameters, which consequently cause changes on all items of the consolidated budget, balance of payments and the expenditure side of GDP, in which descriptive variables of their positions have been included.

The first task of financial programming is the development of the basic scenario, which aims to analyse the situation in the current or subsequent year in case the input assumptions of current economic policies remain unchanged or are worsened.(International Monetary Fund, 2009a). This scenario will occur if the trend continues with further implementation of the current policy in the next year. In this paper for 2014. it started as a basic scenario.

Table 3. Basic - targeted exogenous variables and model derived exogenous variables

\begin{tabular}{|l|}
\hline Basic - targeted exogenous variables \\
\hline GDP growth rate \\
\hline CPI, average annual growth rate in \% \\
\hline Nominal exchange rate RSD/EUR, annual average \\
\hline Model derived exogenous variables \\
\hline GDP deflator, growth rate in \% \\
\hline GDP in RSD billion, current prices \\
\hline Real gross wages, growth rate in \% \\
\hline Real money demand, in \% \\
\hline Private consumption, in RSD million \\
\hline Effective nominal exchange rate \\
\hline Effective real exchange rate \\
\hline Relative unit labour cost, growth rate in \%* \\
\hline Import of goods and services, in EUR million \\
\hline Export of goods and services, in EUR million \\
\hline FDI, in EUR million \\
\hline Portfolio investment, in EUR million \\
\hline
\end{tabular}

* Relative unit labour costs were derived as ratio of ULC for Serbia and average ULC of EU-28.

Source: authors

The second task of financial programming is the development of an alternative scenario, which is based on modified assumptions of previous, i.e. current economic policy and aims to resolve diagnosed problems of 
Filipović M. et al.: Shortage of Domestic Savings and Investments as a Barrier to...

macroeconomic trends. An alternative scenario could be done in several varieties, depending on the set of macroeconomic objectives to be achieved in the new programme. Comparison between the basic and the alternative scenario(s) should indicate the expected direction of the impact of alternative measures of economic policies.(International Monetary Fund, 2009b). The paper also presents the main results of similar models of forecasting economic growth: Post-crisis model of economic growth and development of Serbia 2010-2020 (Stamenković, et al., 2010) and the Fiscal Strategy of the Ministry of Finance (Government of the Republic of Serbia, 2014), in order to allow a comparison of the input assumptions and results.

The main feature of the presented scenario is reflected in the slower growth of economic activity by 2017 , which is derived based on the expected economic dynamics of the largest foreign trade partners of Serbia for the next period. In the period 2015-2017, GDP growth at an average annual rate of $2.7 \%$ is assumed, the average consumer price growth slowly decreases and during the 2015-2017 period there is an average annual growth rate of around $5.0 \%$ (See Table 4).

Table 4. The main assumptions of scenario 1

\begin{tabular}{|l|c|c|c|c|}
\hline & 2015 & 2016 & 2017 & $\begin{array}{c}\text { Annual average } \\
2015-2017\end{array}$ \\
\hline CPI, average annual growth rate in \% & 5,0 & 5,0 & 4,5 & 5,0 \\
\hline GDP deflator, growth rate in \% & 2,7 & 3,4 & 3,4 & 3,5 \\
\hline GDP growth rate, in \% & 0,7 & 2,5 & 3,0 & 2,5 \\
\hline
\end{tabular}

Source: Empirical results of authors

The nominal exchange rate of RSD towards the euro in the period 2015-2017 is derived according to economic activity trends, based on the defined elasticity towards GDP according to determined highly significant inverse relation of these two parameters at annual level, which was one of the bases for the performance of the real effective exchange rate up to 2017. In this context, a relatively stable nominal exchange rate against the euro is expected during the period of 2015 - 2017. This statement is also based on the data from the previous period, which shows that the strengthening of the domestic economy also resulted in the strengthening of the domestic currency. By analysing the data from 2005, it is observed that whenever the GDP growth rate was higher than the growth rate of GDP of the previous year, appreciation of the nominal exchange rate occurred (2010 is the only exception). Also, if the growth rate of GDP compared to the previous year was less or decline was present, the nominal exchange rate against the euro 
Filipović M. et al.: Shortage of Domestic Savings and Investments as a Barrier to...

would depreciate. The inverse dynamics of these two values is shown in the Figure 6.

Figure 6. GDP and nominal exchange rate RSD/EUR

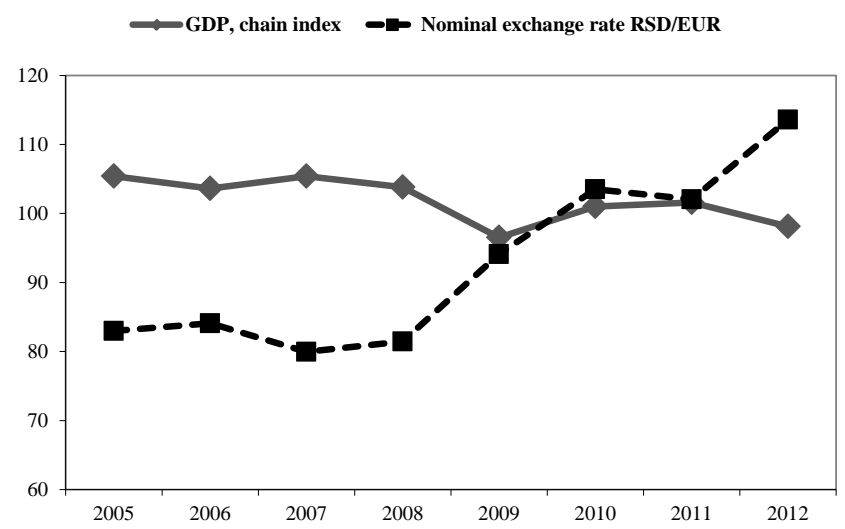

Source: according to the data from Statistical Office of the Republic of Serbia and National Bank of Serbia

Figure 7 presents the relationship between the foreign trade deficit and the nominal RSD/EUR exchange rate, where a clear connection is seen that during every appreciation of the dinar exchange rate the foreign trade deficit rose, and when the dinar depreciated, the deficit fell (2010 is the only exception).

Figure 7. Nominal exchange rate RSD/EUR and external trade deficit

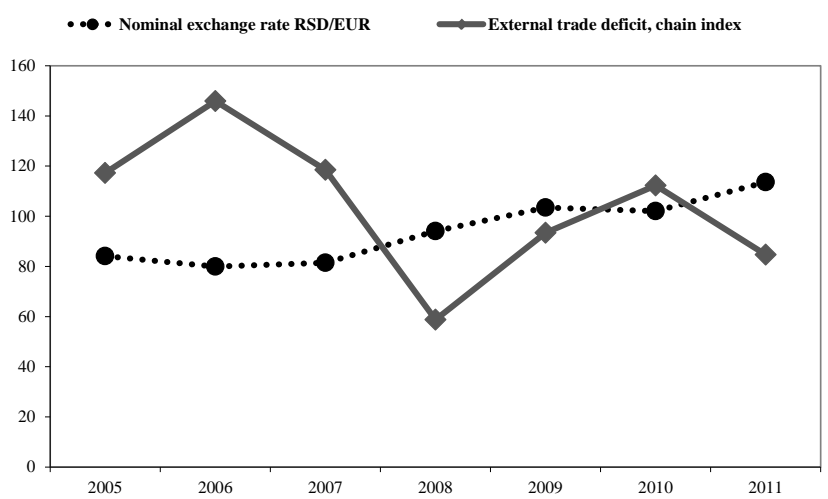

Source: according to the data from Statistical Office of the Republic of Serbia and National Bank of Serbia 
Filipović M. et al.: Shortage of Domestic Savings and Investments as a Barrier to...

The elasticities in the period 2007-2013 established by the model indicate a balanced relationship between real exchange rate appreciation and GDP growth as the basic factors of import growth. In that context, the decrease in imports is fuelled by the deflationary tendencies of CPI as well as by nominal deprecation of the absolute and effective nominal exchange rate, the stated tendencies of which are expressed in both scenarios from 2015 to 2017 . The import of goods and services was modelled depending on changes in the real effective exchange rate and GDP. The established long-term elasticities are defined by the movements of the targets in the period from January 2008 to December 2013. With a view to forecasting both scenarios in the mediumterm (up to 2015), all the analysed monthly econometric models were aggregated at the annual level.

Table 5. Specification of results of the econometric imports model, Jan 2008Dec. 2013

\begin{tabular}{|l|c|c|c|}
\hline & Coefficient & Std. Error & t-ratio \\
\hline const & -6621.7 & 655.5 & -10.4 \\
\hline gdp & 71.9 & 7.3 & 10.1 \\
\hline reer & 1.7 & 1.3 & 1.4 \\
\hline$R^{2}=0.83, D W=(1,6), N$ : Chi-square(2), $p=0,77$, Harvey-Collier test, $(p=0.33)$ \\
\hline
\end{tabular}

Source: authors

In the observed period, GDP growth of 1\% on average brought growth of 71.9 million euros in the import of goods, while 1\% appreciation of the real effective exchange rate brought growth of 1.7 million euros in the import of goods (see Table 5). For the purposes of the econometric analysis, quarterly GDP values were disaggregated (ARMIN method) to the monthly level through the KIPAS indicator (composite indicator of the economic activity of Serbia), which is the combined weighted dynamic of transport, commerce and industry and as such the reference indicator of the economic activity of Serbia on the monthly basis.

Table 6. Specification of results of the econometric import of services model, Jan 2008-Dec. 2013

\begin{tabular}{|l|c|c|c|}
\hline & Coefficient & Std. Error & t-ratio \\
\hline const & -704.216 & 108.5 & -6.5 \\
\hline gdp & 8.7 & 1.2 & 7.3 \\
\hline reer & 0.123 & 0.2 & 0.6 \\
\hline R 2 =0,69, LM test, autocor. $(\mathrm{p}=0,15), \mathrm{N}$ : Chi-square(2), $\mathrm{p}=0,08$, Harvey-Collier test, $(\mathrm{p}=0.96)$ \\
\hline
\end{tabular}

Source: authors 
Filipović M. et al.: Shortage of Domestic Savings and Investments as a Barrier to...

Furthermore, in the observed period, GDP growth of $1 \%$ led to growth of about 8.7 million euros in the import of services, and each 1\% appreciation of the real exchange rate led to growth of about 123 thousand euros in the import of services (see Table 6).

Goods exports were also modelled through the real effective exchange rate and GDP. The obtained long-term GDP elasticities (in the period January 2009-December 2013) indicate that each 1\% growth of GDP on average influenced goods exports to grow by 65.2 million euros, while each $1 \%$ depreciation of the real effective exchange rate increased goods imports by about 2.6 million euros on average.

Table 7. Specification of results of the econometric export of services model, Jan 2008-Dec. 2013

\begin{tabular}{|l|c|c|c|c|}
\hline & Coefficient & Std. Error & t-ratio & $p$-value \\
\hline const & -448.3 & 89.4 & -5.0 & 0.00002 \\
\hline reer & -0.555 & 0.7 & -3.3 & 0.00266 \\
\hline gdp & 7.1 & 0.996 & 7.3 & $<0.00001$ \\
\hline R 2 =0,63, DW=(1,7), N: Chi-square(2), $\mathrm{p}=0,52$, Harvey-Collier test, $(\mathrm{p}=0.32)$ \\
\hline
\end{tabular}

Source: authors

In the case of the services exports model, the impact of GDP and the real exchange rate is defined under the same assumptions as goods exports. In the observed period (January 2008 - December 2013), one-percent growth of GDP led to growth of 7.1 million euros on average in the export of services, while each $1 \%$ depreciation of the real exchange rate increased services exports by about 555 thousand euros on average (see Table 7).

All the stated models satisfy the full specification of all econometric residual and stability parameter tests (Harvey-Collier test), the long-term elasticities of which are also the basis for the simulation of the export and import of goods and services in the period 2015-2017, depending on the pre-defined exchange rate, inflation and GDP targets. 
Filipović M. et al.: Shortage of Domestic Savings and Investments as a Barrier to...

Table 8. Comparative analysis of main scenarios for MEP and Fiscal Strategy model projections

\begin{tabular}{|c|c|c|c|c|c|c|}
\hline & \multicolumn{3}{|c|}{$\begin{array}{l}\text { MEP model - main } \\
\text { scenario }\end{array}$} & \multicolumn{3}{|c|}{$\begin{array}{l}\text { Fiscal Strategy-main } \\
\text { scenario }\end{array}$} \\
\hline & 2015 & 2016 & 2017 & 2015 & 2016 & 2017 \\
\hline GDP growth rate, in \% & 0.7 & 2.5 & 3.0 & -0.5 & 1.5 & 2.0 \\
\hline GDP, in RSD billion, current prices & 4,099 & 4,355 & 4,673 & 3970.5 & 4195.3 & 4454.6 \\
\hline Private consumption,\% GDP & 75.2 & 76.3 & 76.3 & $\cdots$ & $\cdots$ & $\ldots$ \\
\hline Investment, \% GDP & 16.7 & 17.6 & 18.1 & 18.5 & 19.3 & 19.8 \\
\hline Gross National Savings, \% GDP & 12.1 & 13.0 & 15.5 & 13.8 & 14.4 & 15.0 \\
\hline $\mathrm{CPI}$ annual average, $\%$ & 5.0 & 5.0 & 4.5 & 4.2 & 4.1 & 4.1 \\
\hline External-trade deficit, as $\%$ of GDP & -10.2 & -10.2 & -9.3 & -9.4 & -8.5 & -7.6 \\
\hline $\begin{array}{l}\text { Export of goods and services, as \% } \\
\text { of GDP }\end{array}$ & 45.2 & 47.1 & 49.2 & 44.2 & 44.5 & 45.3 \\
\hline $\begin{array}{l}\text { Import of goods and services, as \% } \\
\text { of GDP }\end{array}$ & -55.5 & -57.3 & -58.4 & -53.6 & -52.9 & -52.9 \\
\hline $\begin{array}{l}\text { Foreign Direct Investment, in EUR } \\
\text { million }\end{array}$ & 980 & 1,315 & 1,632 & 1,400 & 1,400 & 1,400 \\
\hline Real gross wages, growth rates & 0.2 & 0.5 & 1.0 & $\ldots$ & $\ldots$ & $\ldots$ \\
\hline $\begin{array}{l}\text { Real exchange rate (\% change - } \\
\text { depreciation) }\end{array}$ & -3.2 & 4.0 & 4.8 & $\cdots$ & $\cdots$ & $\ldots$ \\
\hline Total revenue, \% GDP & 39.5 & 39.4 & 39.9 & 40.3 & 39.1 & 38.2 \\
\hline Total expenditure, \% GDP & 45.2 & 43.3 & 43.2 & 46.1 & 43.8 & 41.9 \\
\hline VAT, \% GDP & 10.3 & 10.7 & 11.0 & 10.1 & 9.8 & 9.6 \\
\hline Pensions, \% GDP & 12.7 & 12.6 & 12.3 & 12.4 & 11.8 & 11.2 \\
\hline Consolidated Balance, \% GDP & -5.7 & -3.9 & -3.9 & -5.9 & -4.7 & -3.8 \\
\hline
\end{tabular}

Source: MEP model - Empirical model of authors for 2015-2017, Fiscal Strategy for 2015 with Projections for 2016 and 2017

\section{Results and Discussion}

Analysis of Serbian macroeconomic performances in last 10 years clearly shows necessity for substantial change of development model from demand oriented, dependent on foreign capital inflow toward production oriented development based on increasing share of domestic savings. Sustainability of development process has to be targeted at innovativeness and raising competitiveness of national economy combined with prudential policy of further foreign investments mainly in high tech export oriented sectors. Position of Serbia at the bottom of CEE countries regarding share of domestic savings in GDP has to be changed through structural reforms that has been already proposed by Serbian Government in 2014. Decrease in public 
Filipović M. et al.: Shortage of Domestic Savings and Investments as a Barrier to...

consumption, reforms of public companies and much intensive incentives for private entrepreneurs and small and medium companies are good orientation for the near future. Positive results in GDP growth expected in 2015 or 2016 have to be accomplished with much higher participation of domestic companies and with engagement of domestic savings through banking channels. Situation in which majority of investments in Serbia is financed by foreign capital is not sustainable in the future as this will obviously lead to appreciation of national currency and additionally de-motivated domestic industrial sector for export and deepen current account deficit. In the situation when further privatization incomes are uncertain and unstable this could be a trigger for prolonged crisis with unsustainable and unpredictable macroeconomic results.

\section{Conclusion}

The analysis of the development trends of Serbia in the last ten years has brought up some interesting points:

- First, opposite to usual belief of domestic experts that higher growth rates of GDP directly leads toward depreciation of nominal exchange rate, model of financial programming shows that acceleration of GDP growth cause appreciation of domestic currency with all its negative consequences

- Second, the import dependence of Serbian economy is extremely high, which means that each time faster GDP growth is achieved, there is a rise in the foreign trade deficit

- Third, the Serbian economy is highly dependent on the export of its products and services and to a relatively small number of countries - our major foreign trade partners, and the recovery of the domestic economy largely depends on the development in these countries

- Fourth, most of the investments as precondition for development are financed by foreign accumulation, while the share of domestic savings in financing development is almost negligible and puts Serbia at the bottom when compared to other countries in the region

- Given the above, an inverse correlation in the movement of GDP and the exchange rate is determined, that is, the domestic currency appreciates in parallel with the rapid growth of Serbia's GDP which further deepens the external deficit, discouraging the export economy (especially its domestic part) and in the long run prevents the achievement of sustainable development in Serbia. 
Filipović M. et al.: Shortage of Domestic Savings and Investments as a Barrier to...

As the basic "cure" for the determined situation and trends in the economy of Serbia, stronger encouragement and achievement of a far higher level of domestic savings in financing the development and distribution of its share in GDP is recommended first, followed by the creation of a set of stimulus measures in favour of amending the domestic savings structure in favour of RSD and the gradual reduction of the degree of "euroisation" of flows in the national economy.

\section{References}

Amisano, G., Geweke, J. (2013). Prediction Using Several Macroeconomic Models, Working Paper Series NO 1537. Frankfurt: European Central Bank. Retrieved from http://www.ecb.europa.eu/pub/pdf/scpwps/ecbwp1537.pdf

Arsić, M., Mladenović, Z., Nojković, A. \& Petrović, P. (2005). Makroekonometrijsko modeliranje privrede Srbije, Beograd: Cesmecon

Berg, M. (2010). The Real Exchange Rate and Growth Revisited: The Washington Consensus Strikes Back?. IMF Working Paper No. 10/58, Washington, DC: International Monetary Fund

Centar za liberalno-demokratske studije. (2012). Rast privatne domaće štednje u cilju ubrzanja privrednog razvoja Srbije, Beograd: USAID Srbija. Retrived from http://www.clds.rs/newsite/CLDS-USAID-PREVOD-RAST-PRIVATNEDOMACE-STEDNJE.pdf

Corden, W.M. (1984). 'Booming sector and Dutch disease economics: Survey and consolidation', Oxford Economic Papers, 36.

Dragutinović, D. Filipović, M. \& Cvetanović, S. (2012). Teorija privrednog rasta $i$ razvoja, Beograd: CID

Easterly, W. (2002), An Identity Crises? Testing IMF Financial Programming. Working Paper number 9. Center for Global Development

Filipović, M. (2010). Održivi razvoj Srbije - mogućnosti sprovođenja, Izazovi evropskih integracija, 2010/9, pp.73-87. ISSN 1820-9459

Filipović, M. (2012). Sustainable Development of Serbia at the beginning of the 21st Century, Industrija, 40(1), pp133-149. ISSN 0350-0373

Geweke, J., Amisano, G. (2011). Optimal prediction pools. Journal of Econometrics 164:130-141.

Government of the Republic of Serbia. (2014). Fiscal Strategy for 2015 with Projections for 2016 and 2017, Ministry of Finance, Serbia. Retrieved from http://www.mfin.gov.rs/UserFiles/File/dokumenti/2015/Fiskalna\%20strategija\%20 2015-2017(1).pdf

International Monetary Fund. (2009a). Course on Financial Programming and Policies. Volume I. The case of Ukraine: Macroeconomic Accounts and Analysis. Vienna: Joint Vienna Institute/IMF Institute-European Division

International Monetary Fund. (2009b). Course on Financial Programming and Policies. Volume III. The case of Ukraine: Financial Forecasting Economic Accounts. Vienna: Joint Vienna Institute/IMF Institute-European Division

National Bank of Serbia. (2014). Retrieved from http://www.nbs.rs/internet/latinica/80/index.html 
Filipović M. et al.: Shortage of Domestic Savings and Investments as a Barrier to...

Smets, F., Wouters, R. (2003). An estimated dynamic stochastic general equilibrium model of the euro area. Journal of the European Economic Association. 1: 11231175.

Smets, F., Wouters, R. (2007). Shocks and frictions in US business cycles: A Bayesian DSGE approach. American Economic Review 97: 586-606.

Stamenković, S., Kovačević, M., \& etc. (2010). Postkrizni model ekonomskog rasta $i$ razvoja Srbije: 2011-2020. Beograd: USAID, SEGA projekat

Statistical Office of the Republic of Serbia. (2014). Retrieved from http://webrzs.stat.gov.rs/WebSite/Public/PageView.aspx?pKey=1 